\title{
A Contribution to the Theory of Imperialism
}

Even as a student, Bauer took an interest in economics. In these early days, he initiated a polemic against the founders of the Austrian School of national economy. ${ }^{1}$ He would return to these topics throughout his entire life. As a theorist, he felt compelled to investigate the degree to which the levels of development achieved by capitalism could potentially facilitate the victory of socialism. As a pragmatist, he had to consider what consequences imperialist policies would have for the working class. Many of his texts were dedicated to observations on the nature of imperialism and its perspectives, its ramifications for the proletariat, and the problem of crises. ${ }^{2}$ Although it is difficult to assess to what extent this was intentional, his analyses became part of an argument about the breakdown (Zusammenbruch) of capitalism that was

1 As Hanisch states in Der große Illusionist (The Great Illusionist), Bauer studied economics under the tutelage of the second-generation Austrian School, Friedrich von Wieser, and Eugen von Böhm-Bawerk. When participating in a seminar by Böhm-Bawerk, he defended Marxian economics against his teacher's critique. See Hanisch 2011, p. 67.

2 These included the following articles among others: Marx Theorie der Wirtschaftskrisen (Marx's Theory of Economic Crises, 1905), Über britischen Imperialismus (On British Imperialism, 1907), Krise und Teuerung (Crisis and Inflation, 1907/8), Österreich und der Imperialismus (Austria and Imperialism, 1908), Der Staat und die Kartelle (The State and Cartels, 1908/9), Das Finanzkapital (Finance Capital, 1909/10), Theorien über den Mehrwert (Theories of Surplus Value, 1909/10), Die Akkumulation des Kapitals (The Accumulation of Capital, 1913), Kapitalvermehrung und Bevölkerungswachstum (Capital Increase through Population Growth, 1914), and Die Wirtschaftskrise im Ausland und in Österreich (Economic Crisis in Austria and Abroad, 1924). In addition, he authored the following works: Die Teuerung. Eine Einführung in die Wirtschaftspolitik der Sozialdemokratie (Inflation. An Introduction to the Economic Policies of Social Democracy, 1910), Großkapital und Militarismus. Wem nützen die neuen Kriegsschiffe? (Big Capital and Militarism. Who Benefits from the New War Ships?, 1911), Volkswirtschaftliche Fragen (Questions of Political Economy, 1921), Die Wirtschaftskrise in Österreich. Ihre Ursachen - ihre Heilung (The Economic Crisis in Austria. Its Causes and its Cure, 1925), Zollfragen in der Lebensmittelindustrie und die Stellungnahme der Arbeiterschaft hierzu (Tax Problems in the Food Industry and the Response of the Working Class, 1928), Kapitalismus und Sozialismus nach dem Weltkrieg. Band 1 Rationalisierung - Fehlrationalisierung (Capitalism and Socialism after the World War. Volume One - Rationalisation and Misrationalisation, 1931), Zwischen zwei Weltkriegen. Die Krise der Weltwirtschaft, der Demokratie und des Sozialismus (Between Two World Wars. The Crisis of the World Economy, Democracy and Socialism, 1936), Einführung in die Volkswirtschaftslehre (Introduction to Political Economics, 1956).

(C) EWA CZERWIŃSKA-SCHUPP, 2017 | DOI: 10.1163/9789004325838_004 
being waged within European Social Democracy. The crisis theory of capitalist economy was a part of that debate.

There were three sources for Bauer's theory of imperialism. ${ }^{3}$ Marx's Capital served as an inspiration, though it was not the most crucial one. From Capital, he borrowed Marx's conceptual framework and research technique, i.e. he utilised the abstract-deductive method to theorise accumulation and analyse business cycles. ${ }^{4}$ Moreover, he employed Marxian guidelines to investigate the historical course of phenomena and processes of social life, as well as Marx's functional-genetic explanatory model. Some elements, however, played a far more prominent role in Bauer's economic thought than the analyses contained in Capital: above all, his fascination with the theory of 'organised capitalism' that Rudolf Hilferding outlined in Finance Capital (1910). ${ }^{5}$ Secondly, his criticisms of Rosa Luxemburg's conclusions, which he elaborated on in detail in Accumulation of Capital (1913). ${ }^{6}$ Challenging Luxemburg, Bauer specifically attempted to demonstrate how wrong she had been in her judgement of the following factors:

- The character of the symptoms that accompany imperialism in the following spheres: economic (monopolisation, cartelisation, the role of bank capital), social (unemployment, impoverishment of the proletariat), and political (role of the state, militarisation);

- Limits to the development of the capitalist mode of production;

3 Grzegorz Kotlarski wrote: "In the second half of the 19th century, the word "imperialism" appeared in scientific literature that explained new practical and economic phenomena of capitalism ... The term "imperialism" (Latin: imperialis - powerful) has English origins. In the beginning, it was used to describe a protest movement of those who advocated Great Britain's colonial policies. It was directed against the activities of the changing government cabinets, which it deemed not energetic enough, to protect the interests of colonial officials. Later, after the reforms of William Ewart Gladstone, "imperialism" referred to the consolidation politics of the British Empire. In the 189os, it became part of the political jargon and synonymous with the politics of conquest and colonial expansion. The leading ideologues of imperialism were Benjamin Disraeli, Cecil Rhodes, and Otto Bismarck' - Kotlarski 1987, p. 142.

4 The fact that he employed the abstract-deductive method, and appealed to Marx as its pioneer, is testimony to the incoherence in his thinking. As mentioned at the beginning of the second chapter, Bauer believed Marx's method to be inductive. The reasons for this kind of inconsistency remain unclear. One can only assume that the interpretation of Marx's method present in Bauer's philosophical thought was heavily shaped by the influence of scientism.

5 See Bauer 1980c, pp. 377-99.

6 See Bauer 1986 and $1979 \mathrm{~h}$. 
- The crisis-prone character of the capitalist economy and factors that might revive it.

We shall briefly preface our reconstruction of Bauer's views on numerous related economic problems (including tendencies in the development of the world economy, the accumulation of capital, business cycles, possibilities of overcoming crises, and the economic transition from capitalism to socialism). The following general remarks are, arguably, the key to Bauer's entire observations on imperialism.

- In economic analyses, Bauer adopted two distinct stances. Firstly, that of a theorist addressing a number of questions: the direction in which capitalist imperialism was developing and its economic, social, and political consequences, the roots of crises and possibilities to prevent and counteract the outbreak of crises. Bauer's second stance was that of a dedicated participating observer who studied empirical reality, described the negative consequences of imperialism for the Habsburg monarchy, explained crises in Austria-Hungary (later just Austria) and sought emergency economic measures to stop them. This internal conflict of Bauer as an economist inevitably shaped his analytical model. He divided his observations into purely theoretical studies on the one hand, and investigations that served the everyday politics of the party - or were subordinated to the author's political views on the other.

- In Bauer's economic studies, his political viewpoint determined his economic position. His analyses were not always inventive, and occasionally they were erroneous. One should not treat this appraisal as a significant objection, given that Bauer was not a professional economist. ${ }^{7} \mathrm{He}$ was, however, an attentive observer of capitalism's developmental tendencies, and of the ways in which these tendencies changed the character of the state. He was also familiar with statistics concerning crises before 1914 and from 1918-31, and knew the state of the European and world economies well. ${ }^{8}$ The value of his analyses, which were insightful and meticulously supported by

7 Bauer's posthumous work, Einführung in die Volkswirtschaftslehre (Introduction to Political Economy, 1956), in which the author discussed the main categories of Marxian economics, testified to his profound knowledge of political economy.

8 Bauer's wide knowledge in these areas and erudition in economic literature are genuinely impressive. He was familiar with the more important economic theories, and the condition of the economies of Europe - especially Germany, Great Britain, and the Balkans - North America, and South America. 
data, is most certainly a historical one, although some of Bauer's prognoses appear prophetic and relevant even today. In his historical period, it was not simply Bauer's insights that mattered, but primarily the goals they were to serve, which were crucial to discussions within the circles of European Social Democracy. As mentioned earlier, one of Bauer's goals was to refute Luxemburg's theory with his hypothesis of a 'self-defensive' capitalist economy - to be sure, an outmoded idea in today's economic science. Another was the defence of Austria's national interest, which involved the preservation of Austria's sovereignty and independence through protectionism. These goals also influenced Bauer's ideas on the transition from capitalism to socialism. What is more, they shaped his views of how the socialist state model would function in the economic sphere, i.e. as part of a centralised planned economy.

Imperialism as a Necessary Stage of Capitalism

With the exception of Max Adler, a determinist view of history was typical for Austromarxists. According to this perspective, socialism would emerge due to the objective laws of historical development, while Social-Democratic politics could only accelerate this historical moment. Informed by the anticipation of capitalism's inevitable breakdown, this view was popular in the Second International, but controversial in German Social Democracy in particular. According to Zenona Kluza-Wołosiewicz, ${ }^{9}$ its roots are in Marx's theory of accumulation. Marx drew the widely recognised conclusion that there is an immanent tendency in capitalism to develop growing contradictions, which are detrimental to development and ultimately lead to its demise. ${ }^{10}$ According to Marx, capitalism's fundamental contradiction is the concentration of the means of production in the hands of a small group versus the social character of production itself, and its inevitable consequence is a socialist revolution in which the proletariat becomes capitalism's gravedigger. For ideological rather than scientific reasons, Marx did not question the inevitability of revolution anywhere in his work. However, it is possible to find remarks warning against a mechanic interpretation of the developmental tendency of capitalism, and even doubts over Marx's own prognosis of a progressive centralisation of production. ${ }^{11}$

\footnotetext{
$9 \quad$ See Kluza-Wołosiewicz 1963, p. 78.

$10 \quad$ See Marx 1990, p. 929.

11 See Marx 1959, p. 246. One has to agree with Paul M. Sweezy when he says of Marx's eco-
} 
The reasons as to why Marx's disciples, who lived in a different economic and social reality - capitalism had entered its imperialist phase - considered it their prime task to verify (or falsify) Marx's prognosis about the direction of capitalist development are obvious. Even then, signs were looming that Marx might have been mistaken about the route capitalism would take, which was synonymous with the demise of revolutionary theory - a pillar of the Marxian system. At the turn of the nineteenth and twentieth centuries, Bernstein's argument about the breakdown of capitalism polarised Marxist circles. Part of the controversy concerned questions surrounding crises: there were opponents of the theory of capitalism's inevitable breakdown on one side, and passionate proponents on the other. Bernstein, Mikhail Tugan-Baranovsky, Conrad Schmidt, Wolfgang Heine and Max Schippel represented the former camp, while Kautsky, Louis Boudin, Heinrich Cunow and Rosa Luxemburg were stalwarts of the latter. The dispute regarding the breakdown of capitalism, which was raging between the opposing camps from 1899-1913, raised a number of questions. Its importance for the workers' movement cannot be overestimated. Indeed, the revolutionary perspectives and strategy that Social-Democratic parties would choose depended on the conclusions drawn here.

At a factual and theoretical level, both sides in this debate based their arguments on economics. But even if Marx's economic theory provided reference points for both, their conclusions were nonetheless diametrically opposed. In a nutshell, the essence of the argument was as follows: orthodox Marxists (1) defended the proposition that production and property would be concentrated and centralised, followed by a concentration of property in commerce and agriculture; (2) emphasised how the negative impact of the monopolies and cartels intensified class antagonisms: (3) drew attention to the increasing polarisation of capitalist society into two basic social groups - capitalists and workers; (4) upheld the concept that the capitalist state has a class character; and (5) provided evidence that the theory of the impoverishment of the proletariat was still relevant. The revisionists took the adverse view on all questions. Hence their belief that capitalism had strong 'self-defensive' powers was matched at an economic level by the concept of capitalism's 'growing into socialism. From this, they drew the practical conclusion that revolution is destructive and had to be abandoned.

As time moved on - especially following the outbreak of World War I - the controversy surrounding the breakdown of capitalism waned in importance for

nomic theory that 'nowhere in his work is there to be found a doctrine of the specifically economic breakdown of capitalist production' - Sweezy 1964, p. 192. 
German Social Democracy, instead giving way to arguments concerning questions of militarism and attitudes towards war. The scarce interest in further discussion resulted not least from the fact that many former advocates of Marxist orthodoxy, Kautsky and Cunow among them, had now adopted revisionist positions. The situation in Austria was different. In the works of Austrian Social Democracy - with the exception of those of Hilferding - the rationale of an inevitable breakdown of capitalism lived on until the demise of the monarchy and the advent of economic decline. For the sake of accuracy, it is worth adding that Henryk Grossman claimed as late as 1929 that the law of capitalist breakdown was 'the fundamental law that governs and supports the entire structure of Marx's thought.12 ${ }^{12}$ This does not mean that it is impossible to find positive remarks about capitalism's endurance and ability to reform in the works of Austrian socialists from 1908-18. Bauer's writings, for instance, offer many descriptions of the self-defence mechanisms that capitalism had developed. Nevertheless, the Austromarxists dogmatically clung to the theory of capitalist breakdown up until 1918, which served the purpose of maintaining the faith of the working class in the imminent victory of socialist revolution. Let us draw attention to another significant difference between German and Austrian Social Democracy, both of which participated in the breakdown debate. In Germany, the positions were sharply divided between resolute critics and apologists. The Austrian Marxists, meanwhile, combined elements of both affirmation and denial of capitalist imperialism. One expression of this was their argument that the capitalist mode of production had set the foundations for a socialist economy. This notion, which the Austrian socialists made an effort to highlight, even provided the basic outline for Hilferding's theory of imperialism. It also defined Bauer's understanding of the development tendencies of the capitalist economy. ${ }^{13}$

Bauer's point of departure for his theory of imperialism was the analysis of the development of capitalist formation. ${ }^{14}$ It began with a reference to the

\footnotetext{
12 Grossman 1992, p. 127.

13 Bauer had already dealt with the formation and development of modern capitalism in his first major work, The Question of Nationalities and Social Democracy (see Bauer 1996). He dedicated many articles that were published in the pages of Die Neue Zeit to specific problems, i.e. colonial, military, customs, and inflation policies. For a collection of these articles, see Bauer 1979, pp. $75^{8-1048 .}$

14 Christian Butterwegge does not share my view: 'Impressed by Hilferding's reflections, Bauer took the market behaviour of cartels, syndicates and trusts - rather than the conditions under which they arose - as a starting point' (our translation) - Butterwegge 1990, p. 86.
} 
main contradiction in capitalist production - i.e. the opposition between the social character of production and capitalist property relations - and the main goal of the capitalist mode of production, the extraction of profit. The fundamental difference between capitalism and earlier formations, which produced to satisfy consumer needs, is its constant striving to increase surplus value. According to Bauer, capitalism passes through three stages: the manufacture capitalism of the sixteenth and seventeenth centuries, the liberal capitalism of the eighteenth and nineteenth centuries, and imperialism, which begins to blossom in the 1890 s. $^{15}$ All three stages are inevitable and historically necessary, i.e. the changes that take place have an immanent and objective character. When describing the first stage, Bauer undertook a comparative analysis of imperialism and 'early capitalism'. He pointed out the similarities and differences in an engaging fashion, concluding that imperialism represents a regression to the capitalism of manufacture, albeit at a higher stage of economic development. In doing so, he was naturally not concerned with the mode of production or market activity, but with the role of the state as a regulator of production. He considered the second stage, liberal capitalism, as a transitional stage characterised by the extreme liberalism that found its full expression in the physiocratic maxim, laissez-faire, and a corresponding economic programme. Capital served as an economic means for state power at the time, and the role of the state was limited. In the economic sphere, it defended the interests of its citizens by introducing tariffs to protect the domestic market. In some economic branches (traffic, steel and energy), it applied protectionist policies. In domestic politics, its role was limited to maintaining the social peace, and in foreign affairs, facilitating peaceful relations to other states. As Hanisch pointed out, Bauer, when analysing liberalism, raised an interesting question concerning the difference between the economic and political liberalism of the Austro-Hungarian monarchy and the liberalism of the whole of Europe. According to Hanisch, Bauer established that Austrian liberalism was detrimental to broad sections of society, since (1) it was orientated towards German peoples, confining Slavic countries to the margins, (2) its driving force was the elite of the German population, (3) it owed its economic and political position to violence and corruption, and (4) it preferred Jews in the economy, whose activities led to the crisis and ultimate demise of liberalism in the monarchy. ${ }^{16}$

For Bauer, three tendencies were decisive in the transition of capitalism to its third, imperialist stage: cartelisation with simultaneous tariff protection, out-

15 See Hanisch 1985, p. 195 .

16 See Hanisch 1985, p. 196. 
flow of capital into economically less developed regions, and the merging of national capitals. ${ }^{17}$ These tendencies were preceded by an increased concentration of industrial and bank capital. ${ }^{18}$ Deriving these ideas from Hilferding's Finance Capital, Bauer referred to three of its core theses and drew conclusions that were just as one-sided as Hilferding's. ${ }^{19}$ He adopted the following points from Hilferding:

- Firstly, the thesis that individual enterprises will merge and become joint stock companies, cartels and trusts with simultaneous strong involvement of the banks. Much like Hilferding, he was convinced that capitalists advance from being production managers to shareholders over the course of this process. ${ }^{20}$ One consequence of the interrupted connection between the ownership of capital and production management is a change in property relations. Company profit is superseded by a new category - 'founder profit' (Gründergewinn). It is a factor of accelerated accumulation accompanied by capital concentration and centralisation, which occurs at the expense of smaller enterprises (which are eliminated). This process is encouraged by the credit policy of the banks, which favour high interest rates, and therefore favour corporations and support the establishment of industry monopolies.

- Secondly, the thesis of industrial and bank capital merging into finance capital. $^{21}$ This type of capital possesses greater financial powers than the sum of capitals of all individual entrepreneurs. Consequently, bank capital seizes industrial capital. Along with Hilferding, Bauer committed an error: he believed this tendency to be permanent. Both disregarded the antagon-

17 Compare Lederer 1965, p. 375. Until 1908, Bauer was convinced that it was impossible for Austrian capitalism to develop towards imperialism. In his later writings, he aptly pointed to the role of German capital in the emergence of Austrian imperialism. German protective tariffs at the beginning of the twentieth century made the import of Austrian agricultural goods to Germany difficult. After the 1905 trade agreement between Germany and Austria, German exports to Austria doubled by 1914, while Austrian exports to Germany remained constant.

18 See Bauer 198ob, p. 170.

19 According to Kluza-Wołosiewicz, Hilferding's Finance Capital (1910) met with greater interest in Russia than it did in Germany. The Russian labour movement brought it to Poland. There are also echoes of Hilferding's theory in the imperialism analyses of two Polish authors: Jędrzej Moraczewski and Oskar R. Lange. See Kluza-Wołosiewicz 1963, p. 259 .

$20 \quad$ See Hilferding 1981, pp. 204-7. Compare Bauer 1976q, p. 847.

21 Hilferding writes: 'I call bank capital, that is, capital in money form which is actually transformed in this way into industrial capital, finance capital' - Hilferding 1981, p. 225. 
istic forces and increasing financial autonomy of big corporations. Hence, Bauer - like Hilferding - drew the dubious conclusion that the combined interests of all entrepreneurs could be consolidated into a central cartel, complete with a newly established world bank controlling and administering all production according to a plan. From this, they unjustifiably further concluded that there was an intrinsic tendency of the world economy to transform into a socialised planned economy. ${ }^{22}$

- Thirdly, the belief that a new organisational form of economic life is created by the policies of the cartels, which strive for a monopoly position on the world market. These policies intensify the struggle against small-scale enterprise, which is economically compelled to integrate in order to survive, even if it can only do so in this modified form. ${ }^{23}$ As a result of this struggle, only big industrial monopolies can survive in the market. ${ }^{24}$ Neither Hilferding nor Bauer hesitated to draw a far-reaching conclusion from these analyses: the cartels would displace small- and medium-sized enterprises from the market and thus 'introduce' a regulative factor to economic life. ${ }^{25}$

On the grounds of economic science, Bauer regarded the development tendencies of imperialism outlined above as inevitable and objective. This is not to say that he failed to see their negative consequences, especially their social effects. The centralisation of production and capital might have a positive effect on technical and economic progress by increasing labour efficiency, yet, according to Bauer, under capitalism this is not synonymous with progress. Technological development increases exploitation and unemployment, as capitalists are not interested in the social implications, but only in the economic effects of new technology, i.e. the maximisation of profits. Another negative phenomenon of centralisation is the constraint on democracy in economic life: it allows a tiny group of powerful capitalists who own the instruments of economic and political power to rise to the top.

\footnotetext{
22 See Bauer 1976q, p. 849 .

23 Lenin, Trotsky and Luxemburg were also convinced that a process of ever more profound global economic integration was taking place.

24 Bauer interchangeably referred to this phase of capitalist development as 'monopoly capitalism,' 'organised capitalism', or 'state capitalism'.

25 Bauer had already developed these three theses in his article 'Das Finanzkapital' ('Finance Capital') - see Bauer 1980c, pp. 377-87. One can find a similar viewpoint in the works of Bernstein at the end of the nineteenth century. Lenin subjected it to criticism in 1901 when he attempted to prove that monopolies would further intensify the contradictions of capitalist economy. See Lenin 1964, pp. 213-16.
} 
In addition to these negative side effects of capital concentration and centralisation, Bauer identified two mutually linked features of imperialism that deepen the problem. Thus far, we have insufficiently touched upon these features: imperialism's international nature and its expansionism. Admittedly, Bauer did not mention them separately in his work, but he clearly recognised that they were connected to other questions. Firstly, he linked the international character of imperialism to the changing roles of the bourgeois state and great economic spheres, and secondly, he linked its expansionism to colonialism and militarism.

Bauer aptly observed that the development of the world economy, which transcends the borders of 'national economies', leads to a more intense struggle between cartels and syndicates for the economic and political sphere of influence. Indeed, the battle of monopolies is a battle of states. For under imperialism, a unification of the interests of finance capital and the state apparatus takes place, which comprises the following realms: the protection of one's own raw material, commodity and labour markets; the export of commodities abroad (in order to postpone the ripening contradictions of the accumulation process at home); and finally, the scramble for international markets and colonies. Bauer shared Hilferding's opinion that the economic role of the state becomes stronger under imperialism, claiming that the state provided the foundations of a national economy. ${ }^{26}$ At the same time, he came out in favour of maintaining or creating big state organisms. He argued that only a big (i.e. independent and strong) state can act as a regulator of socio-economic life, and that only such a state can assert itself in the struggle for economic and political hegemony on the international stage. ${ }^{27}$ In defence of the validity of his viewpoint, Bauer appealed to the work of the bourgeois economists Albert Schäffle, Gustav von Schmoller and AdolfWegner, who regarded countries with vast geographic areas and large populations as autarkic and considered big enclosed state territories to be independent economic units. ${ }^{28}$

Bauer emphasised another consequence of the unification process in the global economy that results from the struggle of monopolies and states for

26 See Bauer 1975b, p. 695; compare p. 703. In Zwischen zwei Weltkriegen (Between Two World Wars), Bauer alternatively uses the terms 'dirigist economy' and 'planned economy' to describe the dependence between the economy and the state - see Bauer 1976q, p. 107.

27 Rosa Luxemburg shared this view - see Luxemburg 1976, p. 129. In Austromarxism, Karl Renner developed the theory of establishing large economic sectors. See Renner 1916, pp. 112-17.

28 Lederer also wrote on this subject. See Lederer 1956, p. 406. 
spheres of influence: the subordination of less economically developed countries to economically stronger national units. Expansionism is therefore an inherent characteristic of imperialism; its framework only maps out the limits of capital accumulation. In special cases, the territory for capital expansion might be domestic insofar as a country contains regions where the capitalist economy is not yet fully developed. In other cases, economies of neighbouring countries that are characterised by a low concentration of capital and low levels of technology are subjected to expansion. Above all, however, non-capitalist territories are targeted. Bauer exposed the power-hungry face of imperialism, yet he also argued that imperialist states would conquer colonies peacefully by introducing trade and replacing barter with commodity production, which would happen with the consent of native populations. He realised that the influx of capital and cheap industrial materials into colonies revolutionises existing production relations, which, in turn, changes their social and political structures. Bauer clearly held a negative view of these processes, and his attitude to colonialism was unequivocally hostile. In his speeches against colonial policy, he considered two viewpoints: that of the population of the conquered country, and that of the working class of the aggressor countries. ${ }^{29}$ The consequences for the colonies are economic exploitation, economic imbalance, the ruin of peasants and small artisans who then fill the ranks of the unemployed, and the deterioration of the living conditions of society's poorer layers. Politically, colonialism means that existing political structures are subordinated to the aggressors for the sole purpose of protecting the capitalist economy. For all social classes (with the exception of the ascendant national bourgeoisie), this means increasing political oppression. It is a natural tendency of subjugated countries to strive for political and economic independence. Hence, national liberation struggles under the leadership of the local bourgeoisie commence. The national bourgeoisie is interested not only in shaking off the yoke, but also in creating its own capitalist economy. ${ }^{30}$

Like many German Social Democrats - e.g. Kautsky, Bernstein, Luxemburg and Schippel - Bauer regarded militarism as an integral component of expansionism. In contrast to the German theorists, however, he barely investigated the militarisation of the economy. It was not so much the economic consequences of militarism and expansionism that interested him, but their social implications. Two of his comments on the role of militarisation in the economic

29 See Bauer 1979d, pp. 828-43.

$30 \quad$ See Bauer 1976q, pp. 837-40. 
cycle and development of capitalism are notable. Firstly, he rejected Schippel's thesis about the counter-crisis effect of militarisation. ${ }^{31}$ He pointed out that armaments and an increase in military and navy spending lead to higher taxation, thus reducing the social capacity to consume and making it more difficult to overcome crises. ${ }^{32}$ Secondly, he proved that all positive effects of the developing armaments industries (acceleration of capital accumulation, economic upturn, expansion of the manufacturing base, increased demand for human labour, guaranteed security of favourable capital investment, reduced unemployment, and improved material conditions for the working class) only last for a short period of time, as militarism has a tendency to expand automatically. This expansion drastically exceeds the initial goals and motives of competing countries. It inevitably leads to war between the major powers, resulting in the ruin of the capitalist economy. ${ }^{33}$

The Socio-Political Context of Bauer's Observations on Imperialism

If one wants to fully comprehend Bauer's statements from 1907-13 concerning the necessity of maintaining colonialism, militarism, and a vast state territory, one should not forget that his motives were not only scientific, but also political. He was chiefly concerned with two things: firstly, the political and economic interests of the Habsburg monarchy and the implications of imperialist policies for the working class; secondly, and consequently, the stance of the Social-Democratic party towards potential dangers unleashed by the development of imperialism.

The very notion of creating vast, economically autarkic state territories was geared towards the protection of a relatively autonomous production sector. Above all, however, the intention was to safeguard the consumer market of the Austro-Hungarian monarchy, whose preservation Bauer passionately defended up until 1917. Arguably, this standpoint predetermined his negative attitude towards Friedrich Naumann's project, Mitteleuropa (Central Europe), which the German section of the SDAP and the Hungarian Social Democrats

31 In German Social Democracy, Max Schippel founded the theory of overcoming crises by increasing the unproductive consumption of the state. He viewed the development of militarism as its most favourable form. See Schippel 1888 .

32 See Bauer 1975c, pp. 780-90.

33 Bauer shed light on the relationship between fascism and imperialism in his later work in the 1930s, which contained a theory of fascism based on the theory of imperialism. I will investigate this in Chapter 8. 
endorsed. ${ }^{34}$ The project was based on the changing role and function of the state in the era of imperialism. It was essentially an economic argument for establishing a union of Middle European states (Germany, Austria-Hungary, Bulgaria and Turkey), which was a political project directed against British, French and Russian capitalism. ${ }^{35}$ Bauer objected to the Mitteleuropa project for national reasons. He feared that the course of development implied in the name would lead to the establishment of a trust which would destroy the domestic economic sector. ${ }^{36}$

For the same reason, he viewed the effects of colonialism upon the economy of Austria-Hungary negatively. That is to say, he believed that colonial policy was an obstacle for domestic economic development: increased armament and navy spending was not conducive to the development of the domestic labour market. The latter was additionally jeopardised by cheaper labour in the colonies. According to Bauer, the import of cheap products, which increased the wage earner's purchasing power, was the only form of colonisation beneficial for the working class of the aggressor country. Convinced that colonisation policies were not a necessary condition for the development of capitalist production, Bauer formulated his credo as follows: 'Even if imperialism is not a means to facilitate accumulation in the first place, it nonetheless serves as a means to further expand its limits and make it easier to overcome crises that are periodically caused by overaccumulation' (our translation). ${ }^{37}$ Incidentally, Bauer's standpoint had no practical influence upon the policies of the SDAP.

34 Friedrich Naumann (1860-1919) - a German liberal, publicist and politician. Founder of the periodical Die Hilfe.

35 It concerned the necessity of creating vast economic territories which would guarantee the capitalist system unlimited production.

$36 \quad$ Hilferding and Kautsky advocated a similar position on this question. See Hilferding 1915. Compare Kautsky 1916, p. 11.

'Ist also der Imperialismus nicht ein Mittel, die Akkumulation überhaupt zu ermöglichen, so ist er doch ein Mittel, ihre Grenzen weiter zu spannen und die Überwindung der Krisen, die periodisch aus der Überakkumulation entstehen, zu erleichtern' - Bauer 1979g, p. 1039. Bauer's critique was part of a wider discussion conducted in the international labour movement at the Amsterdam (1904) and Stuttgart (1907) congresses. The attitude of the Social-Democratic parties toward the colonial policies of the imperialist countries was the topic of debate. While the Social Democrats conceded that any ambitions to conquer hitherto independent states ought to be abandoned, they were unsure about maintaining already existing colonies. They wondered, for instance, whether it might be necessary to preserve the colonies for the continued functioning of the world economy. If economically backward countries were granted a free and independent development, would that constitute a threat to capitalism? 
The Austrian delegate in the committee for colonies at the Stuttgart International Socialist Congress (18-24 August 1907), Engelbert Pernerstorfer, pleaded for an expansive colonial policy. ${ }^{38}$ At the same time, the Austrian Social Democrats voiced their opposition to a resolution that denounced the methods of colonisation. Indeed, in 1917, the party leadership supported the government's colonial policies. Bauer had already been aware since 1910 that the scramble for new sales markets, new raw material markets, and cheap labour in the colonies would lead to the outbreak of war between highly developed countries. He warned of the potential consequences of war for the Austro-Hungarian monarchy: defeat and demise. Taking a long-term view, Bauer claimed that in the case of military conflict, Germany would strive to incorporate Germanspeaking territories to secure an additional reservoir of raw materials and cheap labour for the armaments industry. ${ }^{39}$ In this context, he wrote: 'The collapse of Austria presupposes the triumph of imperialism in the German Empire, in Russia, in Italy ... The Austrian workers cannot place their hopes in German, Italian, and Russian imperialism, which is the enemy of their brothers abroad and the victory of which would diminish their own power at home. 40 From this, he drew the following conclusion: during the epoch of imperialism, the working class is probably not interested in the demise of the monarchy because that would result in the defeat of the proletariat on an international scale. Bauer strikingly exposed an additional feature of German imperialism, namely a nationalism that linked the project of capitalist expansion with the pan-German idea. Its ideologues strove to break the resistance of the German working class against the economic policy of conquest by suggesting that the latter amounted to a struggle for national liberation. Exposing its predatory face, Bauer argued that the fight against German nationalism and its real aim a world war - should be waged as a workers' struggle against imperialism. ${ }^{41}$

For Bauer, a committed Social Democrat, the most significant part of his research into imperialism was the economic and socio-political consequences of expansionism and militarism for the working class. Of course, this is not to say that his analyses were devoid of more general assessments of imperialism's economic and social effects. On the contrary, Bauer avoided the one-sided conclusions so characteristic of many socialist authors - Kautsky and Lenin, for instance - and depicted the results of the new epoch of capitalist development with a healthy dose of sobriety. He argued that many economic phenomena,

$38 \quad$ See Pernerstorfer 1907, p. 112.

39 See Lederer 1956, p. 387 ; compare p. 391.

$40 \quad$ Bauer 1996, pp. 403-4.

41 See Bauer (alias Heinrich Weber) 1909, p. 538. 
which accompany capital concentration and centralisation, are fundamentally important for the harmonious growth of the capitalist economy. Developments such as the export of capital surplus, rationalisation of the manufacturing process, technological progress, and replacing free competition with monopoly market control increase productivity and work intensity. Bauer felt that these processes were positive. He viewed the demise of many branches of commercial production and their consequences - the destruction of small trade resulting from the concentration of capital - as an inevitable side effect of internal development tendencies within capitalism. On the other hand, it is crucial to understand that Bauer did not quietly ignore the negative social and political effects of imperialist policies. More than once, he pointed out that they aggravate class antagonisms and lead to a widening of the economic gap: a small group of capitalists becomes wealthier at the expense of the working masses; petty owners are declassed and join the ranks of contract workers. They also result in falling levels of consumption among the population, declining wages, and rising levels of unemployment. The weakening of democratic structures a result of the growing interventionism of the bourgeois state, the reinforcement of its instruments of power (the police and army) and their deployment in the service of capital - posed, in his view, a serious danger to social life. An expanded army - as he argued in opposition to Schippel - does not bear any benefits for the working masses at all. Rather, it becomes a machine to strangle their resistance, a barrier to their economic, political and social emancipation. ${ }^{42}$

Bauer's merit as far as raising awareness of imperialism's consequences, however, lay not in his general observations, but in his attempt to demonstrate how monopoly policies helped shape the standard of living for the working class. His earlier judgements from the years 1906 and 1907 are not entirely reliable, which resulted from the fact that data on the development of imperialism was sparse and could not provide a base for objective assessment in the early stages of his research. In his later work, Bauer revealed to the working class the dangers and ostensible benefits of capitalism's development towards imperialism..$^{43}$ On the one hand, the period of capital circulation is shortened due to intensified production, and the import of cheap food supplies from the colonies improves the purchasing power of labour. On the other, the positive consequences of capital outflow are neutralised by tariff policies that serve to

\footnotetext{
42 Schippel's analysis concluded that the army of the bourgeois state can be converted into a people's army. Hence, the progress of militarisation can be considered as a way of 'growing into' socialism.

Karl Renner and Max Adler also wrote about this - see Renner 1915; compare Adler 1915.
} 
protect the development of highly organised branches of production, prices set by monopolies, and indirect taxes. Reinforcing his argument, Bauer stated that the development of industrial monopolies reduces contradictions between the interests of industrial capitalists and landowners as the demand for protective tariffs unites both classes. He borrowed this line of argument from Hilferding, who had established a thesis closely linked to underconsumption theory: unlike capitalists, the working class is only interested in the development of the domestic market. The two classes thus assume a mutually hostile stance. With the intention of defending Austria's national interests, Bauer concluded thus from Hilferding's observations: under imperialism, the working class must reject the position of classical Marxism on protective tariffs, ${ }^{44}$ as they are outdated and only support policies that protect the domestic market. ${ }^{45} \mathrm{He}$ justified the struggle of the proletariat for changes in tariffs policies as follows: 'While the profit interests of the enterprises are at odds with the public interest of the national economy, the interest of the working class coincides with the interests of national economic progress. [...] In the struggle against the tariffs policies of the propertied classes, the working class is the champion of national economic progress' (our translation). ${ }^{46} \mathrm{He}$ also associated the protection of the domestic market with the socio-economic benefits that were in line with the policies of the party, which hoped to end the increasing hardship of the working class. Interestingly, for Austrian Social Democracy - unlike Social Democracy in other European countries - the controversial question as to whether there could be talk of pauperisation of the proletariat did not play a decisive role in any period. In the SDAP, the theory of pauperisation was rejected. Only Adler drew attention to the phenomenon of relative pauperisation in his article 'Zur Revision des Parteiprogramms', and protested against the rejection of pauperisation theory at the Vienna Congress of $1901 .{ }^{47}$ Bauer consistently championed the view that the development of imperialism does not lead to

44 About the tariff question, Marx shared Ricardo's position. In 1849, he was not of the opinion that free trade and tariff policies were of great importance for the working class. Marx and Engels advocated free trade.

45 See Bauer 1979k, pp. 113-15.

46 'Während die Profitinteressen der Unternehmen dem Gesamtinteresse der Volkswirtschaft widerstreiten, fällt das Interesse der Arbeiterklasse mit dem Interesse des volkswirtschaftlichen Fortschritts zusammen ... Im Kampfe gegen die Zollpolitik der besitzenden Klassen ist die Arbeiterklasse die Sachwalterin des volkswirtschaftlichen Fortschritts' - Bauer 1975b, p. 700.

See Adler 1901. 
pauperisation in a physical sense but in a social sense: it increases the disparity between the consumption levels of the propertied classes and workers. As one of the few Second International theorists, he was aware that an increase in the consumption of labour power - the result of an intensification of labour linked to technological progress - requires an increase in the means of subsistence for its social reproduction. This additionally depresses the living standard of the working masses. In Die Teuerung (Inflation, 1910), he furthermore wrote about the socio-economic consequences of cartelisation and the disruption of balance between industrial and agricultural production, arguing that it leads to an upsurge in food prices and the growing impoverishment of the working class. As Pfabigan noted, Bauer was convinced that the capitalist order cannot solve the problem of price hikes - it only disappears under socialism. ${ }^{48}$ That is why, as early as 1911, Bauer issued a call demanding that the struggle against price hikes be linked to the revolutionary struggle, bearing in mind that this slogan only had propagandistic value, which was surely his intention. In this stage of his life, Bauer had not mapped out a vision for revolution yet. ${ }^{49}$

The Question of Crises in the Capitalist Economy

When analysing imperialism, Bauer was preoccupied with the capitalist economy's susceptibility to crises. Crucially, the following questions related to this problem:

- Is the cyclical return of crises an objective economic law, i.e. a feature of capitalism that is inherent and inevitable?

- What economic and social consequences do crises leave in their wake, especially for the working class?

- What is the role of crises in creating the foundations of the new social order? Does the imperialist stage of capitalist development itself create the conditions for it to be replaced with socialism? If so, should the proletariat wait for that historic moment, and if not, what tasks for the proletariat does the new situation pose?

48 In 1911, a massive demonstration against unacceptable price rises took place in Vienna. It was suppressed by the police in a bloody fashion, leading to four deaths and hundreds of injuries. Three hundred participants were arrested.

49 See Pfabigan 1985, p. 41. 
Behind these doubts was, in fact, a much more fundamental issue: in the background, the dilemma of revisionism was looming, albeit in a modified form. If the development of capitalism had taken a different direction from that envisioned by Marx, and if capitalism had created self-defence mechanisms, could one then continue to uphold the theory of its destruction by a socialist revolution, or should revolution be abandoned for good? If the theory were to be abandoned, then it could only be replaced with a concept that might reassure the masses that the workers' party had not broken with Marx.

At the outset of further discussion, let us note that Bauer viewed crises as an inevitable phenomenon of capitalist economy. ${ }^{50}$ Concurrently, he claimed that capitalism acquired powers of regenerating itself and would not fall before the world revolution. He disagreed with the revisionist idea that crises progressively decrease in frequency, scope and duration. ${ }^{51}$ Furthermore, he questioned whether crises have a tendency to transform into a great global crisis, as the revisionists claimed. Bauer believed that two types of crises occur during the contemporary development phase of imperialism: conjunctural crises, which periodically result from the global crisis, and structural crises, which are local and rooted in the conditions of the respective countries. ${ }^{52} \mathrm{He}$ viewed each type of crisis from a different perspective: for Bauer, conjunctural crises were a theoretical problem, which is why he addressed them in the debate among European Social Democracy. In contrast, he analysed structural crises as a pragmatist looking for temporary solutions in Austrian conditions.

\subsection{Conjunctural Crisis and the Theory of Overcoming Crises}

Bauer based his theory of the business cycle on an analysis of the global crisis from 1929-31, even if it contained elements of his earlier thought from 1913. His own assessment of the Austrian structural crisis provided the foundations. It was also the source of numerous erroneous assumptions, the most significant of which were his overestimation of the role of (1) monopolies, (2) the demographic factor, and (3) 'slips' in the rationalisation process.

Like Marx, Bauer conceived of the crisis as a disturbance in the process of capital accumulation. ${ }^{53}$ As Marx further explained, this is caused by three

\footnotetext{
5o See Bauer 1979c, p. 794. Compare Bauer 1976l, p. 639.

${ }^{1} \quad$ Kautsky held similar views on this - see Kautsky 1902, p. 136. This led to the thesis of capitalism being in a state of 'chronic depression' that only socialism could cure.

$5^{2} \quad$ See Bauer 1976l, p. 639 .

53 Many authors believe that the classics of Marxism did not produce a coherent or unified theory of crisis and the business cycle. See Sweezy 1964, pp. 207-8. Compare KluzaWołosiewicz 1963 p. 172, and Barczyk and Kowalczyk 1985, p. 106. Indeed, Marx named
} 
factors: the contradiction between the strong productive forces of the economy and the low purchasing power of the population; the anarchy of capitalist economy; and the falling rate of profit. The falling rate of profit in particular is, according to Bauer, fundamental, as it is an objective law of capitalist economy and therefore causes crisis as an inevitable phase within the business cycle. ${ }^{54}$ Hence, Bauer treated the crisis of 1929 as a normal and unavoidable occurrence. He was convinced that this economic meltdown, like the previous one, represented a self-regulatory element and driving mechanism of capitalism. Analysing the causes of the crisis, he arrived at the following conclusions: World War I compromised the global economic balance. Following that, new global divisions gave rise to, on the one hand, closed economic sectors, and, on the other, intensified competition between the imperialist countries for markets and spheres of influence abroad. In Bauer's eyes, the crisis of 1929 was a crisis of overproduction, and the causes of such economic disturbances - Marx was equally convinced of this - are the falling rate of profit and a simultaneous rise of surplus value. That is, a situation in which consumption cannot keep up with the surplus of production capital. Thus, Bauer rejected a theory popularised by the works of J.S. Mill and Jean-Baptiste Say, which remained alive in bourgeois economics until the days of John Maynard Keynes: namely that, in the long term, it is impossible to glut the capitalist market, as there is no disturbance in the $\mathrm{C}-\mathrm{M}-\mathrm{C}$ circulation of commodities. All income from the sale

a number of real causes of crisis in different volumes of Capital, including the contradiction between levels of production and consumption, disparities in the development of different branches and sections of production, and the falling rate of profit. See Marx 1972, pp. 414-15; compare Marx 1959, pp. 483-4. This triggered a wave of criticism among thinkers inside and outside the socialist camp. Among the first to attack Marx's crisis theory were - according to Kluza-Wołosiewicz 196, p. 172 - Bernstein and Mikhail Tugan-Baranovsky. See Bernstein 1899, pp. 66-82, compare Tugan-Baranovsky 1923, p. 197.

54 After World War I, Social Democrats pointed to the falling rate of profit as a cause for the breakout of crisis. Bauer was therefore not alone in claiming this. I shall use the opportunity to make two corrections. Firstly, many economists incorrectly think of Bauer as the author of the claim that crisis does not constitute an inevitable phase of the business cycle because periods of boom and depression are crucial for the cycle. They also wrongly accuse Bauer of providing with this thesis - which, nota bene, he never put forward a basis for Hilferding's theory of crisis-free cycles. See Mendelson 1959, p. 96. Compare Sweezy 1964, pp. 447-8. Secondly, Hilferding's theory of 'organised capitalism' did not exclude the possibility of crisis in the first phase, i.e. before a central cartel that totally controls all production is established. Hilferding himself had doubts that such a cartel would be created. 
of commodities produced, according to this theory, is invested into purchasing articles of consumption and furthers the means of production..$^{55}$

Having investigated the capitalist economy's susceptibility to crises, Bauer felt obligated to raise further interesting economic questions. Do, for instance, other causes for the disruption of the economy accrue from the fundamental contradiction between production and property relations? Is it possible to counteract the emergence of overproduction - and if so, how? Can the development of imperialism lead to a modification of the business cycle? In other words, the question was whether the capitalist mode of production could protect itself against crises upon entering the stage of imperialism.

I will preface Bauer's answer with an important comment. Bauer, who had authored The Explanation of Imperialism, embarked on his own distinct path when discussing the problems of overproduction and crises under imperialism. He made no concessions to positions that were popular in Social Democracy, and which were mainly advocated by German theorists at the time. True, his theory contained echoes of fashionable explanatory models of crises, such as the theory of disproportionality between different economic branches and sectors, low consumption levels among the masses, and the theory of 'organised capitalism. But if the solutions he offered were not always satisfactory - an objection one could raise against most of the theories of his period - they were at least innovative. Most of all, Bauer avoided the kind of one-sidedness that characterised other voices in the debate on crises from 1901-14. Tellingly, two opposing camps emerged from this debate, which went on to defend their positions passionately for almost 15 years:

- Bernstein, Tugan-Baranovsky, and especially Hilferding, among others, represented the first camp. These authors explained crises as resulting from disproportion between individual economic branches and looked to the centralised planned economy of the monopolies and banks for countermeasures.

- The second camp counted among its protagonists Jean Charles Sismondi, John Atkinson Hobson, Schippel, Kautsky, Luxemburg, and the Russian Narodniks. They ascribed the troubles of capitalism to the underconsumption of the masses, suggesting either the introduction of high wages or the flight to foreign markets in order to overcome them. ${ }^{56}$

55 Jean-Baptiste Say developed this theory in A Treatise on Political Economy - see Say 2000. Bauer criticised it in Bauer 1979c, p. 791.

$5^{6}$ I am fully aware that the division depicted here is a gross simplification. However, the 
Displaying an acute sense of intuition in contrast to the theorists of either camp, Bauer identified a fact that had remained unnoticed in the debate among Social Democrats. The relationship between individual economic branches and sections, as an aspect of the social process of production, is not separate from the social capacity to consume - the two are interdependent. This concept was decidedly novel: Bauer drew on both theories (disproportionality and underconsumption) to explain the causes of crisis, arguing that capitalism's possibilities of self-defence lay in overcoming its tendencies to issues such as disproportion and underconsumption. However, Bauer attributed a greater role to the regulatory properties of the consumer market than he did to a balanced relationship between the two departments of social production. ${ }^{57}$

When formulating his conception of saving capitalism from crisis, Bauer took his critique of Rosa Luxemburg's theory as a starting point. He had criticised her text, The Accumulation of Capital, as early as $1913 .{ }^{58}$ Let us therefore briefly reiterate the theory that Bauer considered to be Luxemburg's most theoretically misguided - and therefore dangerous - for the Social-Democratic movement. Like Marx, Luxemburg thought that capitalism's real goal was not to cover society's consumer needs, but constant profit maximisation. At one point, however, she did not concur with Marx: she instead questioned his view that there could be unlimited capital accumulation, arguing that the end of capitalism is inevitable when it meets its limits in the form of closed borders. She did not attach any major importance to the evolution of the domestic market, as she believed that its capacity to absorb capital was limited - the cause of recurring crises in highly developed countries. Crucially, Luxemburg cited the existence of non-capitalist countries as a core prerequisite for any further capital accumulation. Hence, she assumed that capitalism meets its limits of development and collapses the moment it absorbs and transforms the last non-capitalist elements. Kautsky put forward a similar viewpoint, according to which the existence of agricultural countries was an imperative for the development of capitalism. For Kautsky, their transformation into industrial nations implies the end of the system. ${ }^{59}$

Bauer far from accepted these suppositions. As readers will remember, he rejected the theory of overcoming crises by expanding foreign markets through

protagonists of both camps did share a basic idea, while their more detailed analyses were very different. To dissect the problem in detail would go beyond the scope of this book.

57 Production is divided into two major departments: the first is the department of means of production (I); the second is the department of articles of consumption (II).

58 The relevant article appeared in Die Neue Zeit on 7 and 14 February 1913.

59 See Kautsky 1910, p. 222, and Kautsky 1911. 
the conquest of colonies. As far as Bauer was concerned, Luxemburg made a fundamental error. She believed that her premise of constant consumption on the part of the working class under conditions of expanded reproduction was an indisputable axiom. This led her to the erroneous conclusion that capitalist markets in themselves could not realise surplus value. ${ }^{60}$ What is more, if one accepts her claim that capital accumulation is impossible in closed systems, then only exporting commodities to non-capitalist countries can save the capitalist economy. However, the capitalist economy does not exclude the possibility of importing raw materials from these countries. Bauer based his main proposition on one conclusion he had drawn from his critique of Luxemburg's theory: the accumulation of capital is possible, even necessary, in isolated capitalist countries. ${ }^{61}$ Attempting to identify the prerequisites of capital accumulation in a closed system, he cited two indispensable, mutually dependent conditions:

1. The necessity of a proportionate development of the two departments of production (I and II). When making this argument, he drew on Hilferding's theory of 'organised capitalism'.

2. The demographic factor: growth and drops in population must be proportional to the development of the productive forces, i.e. proportional relations between the productive forces and the consuming power of society must be maintained. ${ }^{62}$

To substantiate his position, Bauer appealed to Marx's schema of expanded reproduction. From this schema, it follows that crises are a consequence of imbalance between the production value of the first ( $\mathrm{I}$ - means of production) and second (II - articles of consumption) departments of production. When investigating the causes of imbalance, however, Bauer did not conform to the analysis provided by Marx, who rejected the interpretation of the cycle as a phenomenon of the money sphere. Like Hilferding, he instead argued that the imbalance of prices in different departments of production was decisive, yet did not go into detail about the causes of this imbalance. ${ }^{63}$ In his study

\footnotetext{
6o Bukharin drew attention to this error of Luxemburg's in Bukharin 1972, pp. 166-7.

61 See Bauer 1986, p. 108. Note that Bauer stressed political and national factors when defending this: in the period leading up to the fall of the monarchy, it was a matter of preserving its national sovereignty, and in the period of the First Republic, a question of confirming its development capacities.

62 See Bauer 1980f, pp. 887-8.

63 Hilferding emphasised the influence of technological progress upon the disproportional-
} 
of the capitalist economy, Bauer did not so much foreground the importance of production as he highlighted the significance of the market. Differing from Marx, he did not link changes in the rate of profit with the price of commodities (which, according to Marx, was a derivative of the organic composition of capital). His premise resulted in a contradictory thesis: it is enough to regulate prices in order to expand production infinitely. ${ }^{64}$ Bauer presumed that the sphere of circulation is the most important sphere for the capitalist economy and must therefore be controlled. According to him, this seemed a very easy task: it would be enough to establish a balance between the first and second departments of social production. Bauer was certainly unaware of the writings of Cunow and Lenin, who had both demonstrated that the first department is relatively independent from the second, and had pointed to the source of this independence. ${ }^{65}$ When analysing the correlation between the two departments, Bauer concluded that the pace at which the manufacture of the means of production develops merely depends on mass consumption, this being in contrast to the production of articles of consumption. One can find a substantial amount of further incorrect conclusions. Let us briefly look at two of them, keeping in mind that they are worthless from an economic point of view:

1. A huge amount of commodities manufactured in the first and second departments can be consumed. That is because the surplus value extracted in both departments only increases at a rate at which its consumption matches population growth. Hence, the workers' capacity to consume only grows at the same rate as their numbers. The capacity of the whole of society to consume precisely reflects the increase of surplus value. The tendency to maintain this balance is inherent to the capitalist mode of production because the accumulation of capital 'adjusts' to demographic growth - this,

ity between the departments of production: in branches of industry with a high organic composition of capital, investments are the highest. Hence, the expansion of their production base requires longer periods. Supply cannot keep up with demand, which inevitably leads to price rises (thus to higher profits) and attraction of capital. This, in turn, gives rise to excessive capital accumulation and overproduction, which surpasses the demand for commodities from industry branches with a low organic composition of capital.

64 See also Mattl 1985, p. 94.

65 See Cunow 1903. Compare Lenin 1972, pp. 155-6. As the economist Lev Mendelson acknowledged, the disproportionality between the development of the first and second departments under conditions of expanded reproduction is permanent, and reflects the contradiction between production and consumption. See Mendelson 1959, p. 60. 
precisely, is its self-regulating mechanism. ${ }^{66}$ The limits of accumulation are determined by the supply of labour power. ${ }^{67}$

2. Surplus value cannot be exported abroad because that would effectively inhibit production in both departments - foreign investments make accumulation impossible (Bauer did not take all possibilities of foreign investment into account, including the purchase of raw materials and labour power at lower prices than at home). Policies that accelerate the development of the domestic market are in the interest of the proletariat. ${ }^{68}$

Alas, one cannot conclude from Bauer's comments on the mechanisms of the capitalist economy whether or not he believed it possible to completely abolish this phenomenon under capitalism. Like Hilferding, he assumed that it would only become possible to avoid crises once the anarchy of the capitalist economy was abolished and a planned economy introduced. ${ }^{69}$ As mentioned earlier, Bauer thought that the regulating organs of the economy - monopolies, cartels, banks, and the state that assumes control over economic life - already fulfilled this function to some extent. ${ }^{70}$ As they eliminate disproportions between the individual branches by changing the business cycle, they moderate crises. ${ }^{71}$

66 See Bauer 1986, p. 106.

67 Compare Haussmann 1979, p. 229. In 1929, Bauer claimed in his speech to the trade union congress that the crisis in Austria would be overcome in eight years, as the relation between population growth and mortality rates would change for the better during this period. To support his statements, Bauer drew up a scheme of expanded reproduction. According to this scheme, the accumulation rate mechanically depends on the population growth rate and the complex growth rate of constant capital (the accumulation rate was purportedly unchanging, constant capital would grow by 10 percent and variable capital by 5 percent). As Sweezy states, Henryk Grossman drew on Bauer's scheme when performing his complex calculations. They led him to the opposite conclusion to that of Rosa Luxemburg: due to the lack of surplus value, capitalism would collapse after 34 years.

68 As Robert Haussmann observes, Bauer's views on this concerned the Austro-Hungarian monarchy. In Czechia and Lower Austria, the proportion of the industrial working class in relation to the total number of employed reached its peak at the beginning of the twentieth century. People married late, the birth rate declined, and the market boasted an excessive supply of commodities. In other parts of the monarchy - Galicia, Dalmatia and Carniola - the process of capital accumulation was slow and birth rates high. Given the weakness of foreign trade, the development of the domestic market was the only possible way to industrialise the country. See Haussmann 1979, pp. 229-30.

69 See Bauer 1980, p. 55 .

$70 \quad$ See Bauer 198ob, p. 174 .

71 Hilferding described this tendency in a more transparent manner than Bauer: 'As long 
This reasoning was based on two arguments, the first of which was pure speculation and was not backed by any evidence: if, for instance, cartels co-operate in setting monopoly prices, this amounts to regulating the movement of prices. The second argument was essentially the same misguided premise that also misled Hilferding: money originates in the act of exchange, the percentage rate being the result of the supply of money capital and demand for it. From this it follows that banks set money supply and percentages arbitrarily. In this manner, they also control and regulate production levels. Alas, Bauer's judgement was incorrect.

\subsection{Structural Crisis and Ways of Overcoming It}

Bauer paid particularly strong attention to analysing the crises that occurred in Austria from 1921-33. Alluding to the additional crisis that Engels distinguished in his work - also known as transitional crisis - he concluded that two types of crises had occurred in his country: conjunctural and structural. The latter, according to Bauer, resulted from the specific conditions and relations

as capitalist production is superimposed upon widespread production for use and noncapitalist, artisanal commodity production intended for a local market, the full impact of crises is felt only by the capitalist superstructure. They affect branches of production where sales may be brought almost to a standstill because the circulation which is absolutely indispensable for the turnover of goods in society is provided by handicraft production or by domestic production ... As capitalist production develops handicraft and domestic production are largely destroyed. The impact of a crisis is now felt by a system of production, the contraction of which is limited by the necessity of satisfying social needs on a much larger scale, both absolutely and relatively ... Changes in the character of crises are also bound to follow the advance of capitalist concentration. The ability of an enterprise to survive increases with its size ... Along with the concentration of firms the scale on which production can be maintained also increases' - Hilferding 1981, pp. 289-90. Kautsky and Luxemburg took an opposing view to that of Hilferding and Bauer, claiming that the effect of the monopolies, which aim for total domination of all branches of production by eliminating competition, intensifies the anarchy of the capitalist economy and accelerates the crisis. See Kautsky 1899, pp. 146-7; compare Luxemburg 2004, pp. 137-8. The practical conclusions that Bauer drew from this analysis should also be mentioned in passing. From his point of view, a balance between the supply and demand of commodities was an ideal situation for the working class (and, according to him, Germany had achieved such conditions). However, the fact that demand depends on the supply of labour power should have led him to the following conclusion: a disproportion between the extent of accumulation and the number of workers results in labour emigration (Russia, Austria-Hungary), which divides the proletariat. A state of balance is the most beneficial for the working class: it has fewer reasons to rebel, so its organisation, unification, and consciousness-raising can proceed smoothly. 
in Austria-Hungary. In his analysis, he focused on the causes that led to a structural crisis in Austria (especially in the years 1921-2), while being less interested in its course and consequences. ${ }^{72}$ Speaking as a dedicated politician rather than as a theorist, Bauer appealed to fact to reveal the complexity and diversity of factors that decisively influenced the recession of the Austrian postwar economy. He included the following causes: (1) economic - Austria's loss of economic territories, resulting in a smaller material, domestic and labour market, the outflow of foreign capital and the weakness of domestic capital, the introduction of protective tariffs on commodities exported from Austria; (2) demographic - decline in population and changes in its structure; (3) political - the necessity of paying war reparations; (4) technological-administrative - poor work organisation, low efficiency and quality of work due to insufficient technological progress, and the introduction of new scientific solutions. ${ }^{73}$ I will allow myself to disagree with Siegfried Mattl, according to whom Bauer overlooked an important aspect when explaining the causes of structural crisis. In Mattl's view, Bauer neglected the policies of domestic banks, which orientated towards exporting capital to Eastern Europe instead of promoting domestic production, this being unfavourable to Austria. ${ }^{74}$ In fact, Bauer did notice this aspect - yet his analyses led him to conclusions which were not entirely correct: that the process of work rationalisation can provide a foundation for preventing crises, and that technological development is only possible in vast economic territories. Notably, the second conclusion had political undertones and served to buttress an idea propagated by Bauer: that of annexing the German part of Austria to the German Empire.

After the fall of the monarchy, Bauer had doubts as to whether a country as small as Austria could survive, which served as one of his reasons for demanding the annex. Nonetheless, he was against the idea of Austria becom-

72 The labour market of the First Republic had the characteristics of a semi-colony: in the best year, the unemployment rate was at 8.3 percent. The official statistics served to conceal the dramatic situation in the industry, where the unemployment rate was at 30 percent in 1927. Compared to the period before the war, the investment ratio had gone down. Not before 1929 did the total industrial output reach the levels of 1913 . Already in 1929, however, the crisis affected steel production and the paper and textile industries - in 1930, production in these branches fell by $5^{\circ}$ percent compared to the year before. In 1933, industrial production decreased by 38 percent compared to 1928 , and unemployment affected 33 percent of those capable of work. See Weber 1984, p. 38 .

73 See Bauer 1976l, pp. 639-40.

74 See Mattl 1985, p. 83 . 
ing dependent on other European countries. His comments on the causes of structural crisis from 1921-2 became the foundation for the Social-Democratic party's economic recovery programme for Austria, which it introduced in 1922 when debating the government on the results of the 'Geneva Convention' (also known as Upper Silesian Convention). The Social Democrats, Bauer in particular, protested against the economic and political dependency that resulted from the convention, as well as dreaded (justifiably) the consequences of the 'recovery programme' for the poorest layers of the population. The minister of finance, Dr Spitzmüller, had worked out a programme drawing on the economic thought of Keynes: economic recovery would be brought about by increasing the demand for investments (i.e. developing the municipal economy and introducing public works financed by the state budget), and overcoming the crisis by utilising inflation policies. ${ }^{75}$

In those days, Bauer was critical of Keynes's theory. ${ }^{76}$ Because of the country's small size and economic weakness, he did not believe that it could be put into practice in Austria. In October 1921, he formulated his own programme for saving the Austrian economy. It drew on the theory of cyclical crises, and also on Hilferding's notion of the state as a force that accelerates the process of overcoming crisis. As mentioned in the first part, this programme was effectively a suggestion to win financial means by taxing wealthier social groups and foreign bank accounts held by Austrian citizens. In addition, a state front of public works - comprising road, water supply line, railroad and postal service works was to be set up and financed by domestic loans. For all their differences, both programmes noticeably contained a common element: they placed emphasis on stimulating investment by the state for the purpose of creating a labour market that might help to overcome the crisis. ${ }^{77}$ The government reacted negatively to the demand that the costs of crisis be shared across all social classes, and it

75 John Maynard Keynes (1883-1946) - a British economist, finance expert, politically dedicated publicist, initiator of the International Monetary Fund and the International Bank for Reconstruction and Development. He advocated a politics of strong intervention of the capitalist state into economic life in order to prevent crises. In his theory, he stressed the role of investment in maintaining the balance of capitalist economy (employment rates depend on demand, and demand depends on investment rates).

76 He strongly protested against one element of this theory in particular: the proposition to prevent crises by regulating the value of money in relation to gold, thus attempting to maintain the balance between the conjuncture and tariffs. Bauer thought Keynes's theory had a political character: in his view, it served to defend Britain's financial independence from the United States. See Bauer 1976h, p. 253.

77 It is worth mentioning that the foundations of the economic regeneration project, i.e. the creation of a labour market in the sense of anti-cyclical economic policies conducted by 
rejected the Social Democrats' financial plan tout court. By doing so, it disassociated itself from the prospect of co-operating with the Social Democrats on economic questions. ${ }^{78}$

As noted earlier, the 'Geneva regeneration' that the government introduced resulted in the anticipated stabilisation of the economy, yet at the same time, as the Social Democrats had feared, it deepened the polarisation of society. The costs of overcoming the crisis were shared unequally, hitting the poorest layers of society - including pensioners, disabled war veterans, and the unemployed hardest.

\subsection{Rationalisation Crisis}

In this passage, I will not content myself with Bauer's view of the conjunctural and structural crisis because that would not exhaust the subject. What is more, Bauer's opinion on crises changed somewhat in 1931. This evolution was conditioned by the threat of fascisisation in Western European countries, as well as indirectly - by his hopes for a democratic development in the Soviet Union. In his 1931 work Kapitalismus und Sozialismus nach dem Weltkrieg Bd. 1 Rationalisierung - Fehlrationalisierung (Capitalism and Socialism after the World War, volume 1 - Rationalisation and Misrationalisation), Bauer referred to the crisis of 1929 as a rationalisation crisis, i.e. a crisis of economic and technological progress..$^{79}$ The main question that arose here pertained to the causes of degeneration and errors in the rationalisation process. He offered one answer: the capitalist mode of production itself is to blame, as it contains the inherent contradiction between capital and labour. To defend his thesis, he pointed out that entrepreneurs strive to reduce costs rather than reduce the social costs of production. This is consistent with the practice of claiming public subsidies financed by tax money that is equally common today. Bauer just as sharply denounced the negative consequences of rationalisation such as unemploy-

the state, were laid by Gunnar Myrdal in Sweden, and - interestingly - in 1933 by Otto Bauer in his work Arbeit für 200.00o (Workfor 200,00o). In 1927, Bauer and Renner pleaded for state concessions to enterprises in the name of the party leadership; they believed that in this way it was possible to stimulate the economy and reduce unemployment. In the SDAP, Johann Schorsch warned that such an intervention might bring 'technological unemployment' in its wake, yet his opinion was not taken into consideration - see Mattl 1985 , p. 90.

$7^{8}$ Hans Kernbauer demonstrated the negative consequences of government policies for the economy and state finances in Kernbauer 1990, pp. 324-5.

79 Bauer intended for this work to be a study in four volumes, but only the first was published. It was not very well received in Austria, and criticism was strong. See Chaloupek 2009. 
ment, the expansion of industrial bureaucracy, and occupational diseases resulting from more intensive labour. He drew the following conclusion:

The social order can only be rationalised in the struggle of the working class against the capitalists. If, when, and in what ways the working class will be able to accomplish the rationalisation of the social order, however, will depend on the successful construction of socialism in the UssR on the one hand, and democracy asserting itself in Europe on the other. ${ }^{80}$ our translation

It is no wonder that Bauer was impressed by the centralised, state-owned Soviet economy of the 1930s, which allowed the country to master crises caused by the external tensions of capitalist economies. His positive judgement of the Soviet economy was undoubtedly a result of his personal beliefs, but citing Russia as an example also served as a foundation for a broader thesis: in a socialist economy, crises disappear, and this process will go hand in hand with full rationalisation. This is the key to a question that will conclude the issue.

Like Marx, Bauer assumed that objective conditions for building the socialist order are achieved when the concentration and centralisation of capital is at its highest levels. At the time when he established his theory, the Social Democrats were guided by the notion that imperialism would naturally develop towards planned capitalism. Bernstein and Hilferding in particular highlighted this thesis, although they arrived at fundamentally different conclusions. Bernstein demonstrated that capitalism had already laid the social foundations for socialism (i.e. the concentration of production accelerated its socialisation, the process of capitalism's 'growing into' socialism was permanent and uninterrupted, and the class struggle was waning). Hence, calls for revolutionary action were no longer substantiated or justified. While Bauer agreed with the eco-

8o 'Die Rationalisierung der Gesellschaftsordnung kann nur errungen werden im Klassenkampf der Arbeiterklasse gegen die Kapitalisten. Aber ob und wann, auf welchen Wegen und mit welchen Mitteln die Arbeiterklasse die Rationalisierung der Gesellschaftsordnung durchzuführen vermögen wird, wird abhängen einerseits von dem Gelingen des sozialistischen Aufbaues in der Sowjetunion, andererseits von der Behauptung der Demokratie in Europa' - see Bauer 1931. 
nomic arguments of the far more revisionist Bernstein, he did not accept his radical thesis. He was much closer to Hilferding's perspective, fully subscribing to his insights and conclusions. ${ }^{81}$

It would go beyond the scope of this book to discuss Hilferding's theory exhaustively. Let us nevertheless look at some of his observations. According to Hilferding's analysis, the development of capitalism sharply aggravates class antagonisms, leading to a bipolar social structure of a new type that consists of the financial oligarchy and the working class. Because administration is separated from production and property, production was socialised. From these observations, Hilferding concluded that the domination of finance capital over industrial capital is the highest development stage of capitalism, and the initial stage of socialist socialisation. ${ }^{82}$ Hilferding identified political consequences in this inner tendency of capitalist development: the socialist elements in the capitalist state and society would automatically become stronger. In other words, one should view socialism as the result of a gradual evolution of 'organised capitalism', given that capitalism 'as such' is working towards its own abolition. One should not attempt to accelerate this moment because in all forms of society based upon class antagonisms the great social upheavals only occur when the ruling class has already attained the highest possible level of concentration of its power. ${ }^{83}$ The financial oligarchy would soon find itself in a similar situation, and then it would suffice if the organised labour movement simply took power under its party leadership. It is worth noting that Hilferding's concept - unlike the views of the revisionists - does not exclude the possibility of revolution. However, it places a stronger emphasis on the smooth progression of socialisation in the socialist state - after all, it is argued, capitalism has already laid the foundations in the shape of a planned economy. ${ }^{84}$ Hilferding's vision of the economic future of the world contained the establishment of a main cartel that would regulate the whole of production and a world bank appointed to administer finance. The activity of these institutions would lead to the abolition of

81 Peter Rosner engagingly and transparently discusses the theory of Hilferding's contained in Finance Capital. He critically examines it and demonstrates how it affected the political practice of Austrian Social Democracy and the socio-political development in Europe. See Rosner 1987, pp. 11-35.

$82 \quad$ See Hofmann 1971, p. 186.

83 Hilferding 1981, p. 369 .

84 In Poland, Oskar Ryszard Lange was a proponent of 'organised capitalism'. All the same, he did not endorse the conclusion of a 'growing into socialism' that Bernstein, Schmidt and Renner had drawn from it, subjecting their theories to sharp criticism. See Lange 1929, p. 70 . 
commodity and money exchange in the socialist economy - their goal was not to maximise profits, but to expand production. ${ }^{85}$

Bauer adopted Hilferding's statements with minor reservations, to which I shall return later. ${ }^{86} \mathrm{He}$ was convinced that the Soviet Union had assumed the role of a central planner and accomplished economic transformations in the spirit of socialism..$^{87}$ This explains why he attached so much importance to rationalisation processes in the USSR and obsessively clung to the idea that only the world revolution could end capitalism for good. This clearly distinguished him from the revisionists. What he had in common with them, however, was his belief that there could be no question of a sudden transition from capitalism to socialism in the economy. As late as 1928 , he defended the model of a mixed economy whereby economic decisions are made by representatives of cartels and the government at joint conferences (I will discuss this in more detail in Chapter 5).$^{88}$ Bauer prefigured the so-called convergence theory that would become popular in the 1970s and whose proponents would include John Kenneth Galbraith, Walter Bickingham, Pitrim Sorokin and Raymond Aron. Its key concept alluded to a convergence between capitalism and socialism thanks to the scientific-technological revolution. Convergence theory also recommended the creation of a mixed socio-economic system that unites positive elements of both economic models.

To conclude my observations, I would like to cite another interesting comment of Bauer's. Although he believed that the process of rationalisation would eventually lead to a socialist economy - a fashionable idea among Social Democrats at the time - another popular view was alien to him: the idea that the economic goal of socialism would be production for the market, but not for profit. According to Bauer, socialism would not raise the standard of living by modifying the distribution of surplus value (which must be used for accumu-

85 The works of Luxemburg and Bukharin also contain the notion of moneyless exchange in the socialist economy.

86 See Bauer 1931. Bauer broke with the notion of 'growing into socialism' of the capitalist economy under the impression of Nazi Germany's armament policies in the mid-193os. Note, however, that this work of Bauer's contained original studies of the problems concerning cycles in agriculture, cycles in the production of gold, cycles in the war economy, the influence of the credit system upon the modification of the course of cycles, and the relationship between profits, prices, and wages. Furthermore, it boasted his own formulation of the 'law of the rate of profit'. Michael R. Krätke discusses these questions comprehensively and transparently - see Krätke 2008, pp. 173-8.

$87 \quad$ See Bauer 1976p, p. 117 .

88 Compare Mattl 1985, p. 95. See also Bauer 1976q, p. 375. 
lation, technological development, and educational purposes), but by raising work productivity. The latter, in turn, can be achieved by intensifying the social division of labour. With this thesis, Bauer consciously contradicted Marx's assumption that abolishing the division of labour was an important condition for implementing the socialist order.

To summarise, it would certainly not be a misrepresentation to say that Bauer's economic thought - which contained many errors, but also many interesting insights and conclusions - was barely relevant to the policies of the SDAP. For the workers, it was incomprehensible and often went directly against their immediate interests - for instance, concerning wage increases. I have tried to highlight the strong and weak points in his line of thinking when depicting its individual elements. What is more, Bauer's economic observations did not receive as much attention in the Second International as the respective works of Kautsky, Luxemburg, Lenin, Tugan-Baranovski, Hilferding, and others. The decisive factor was that Bauer's economic theory evolved at the wrong time to make much of an impact. The years from 1896-1913, in contrast, were a time of intense debate about the economic future of capitalism. They were followed by a period during which more critically important issues, such as the outbreak of World War I, the fascisisation of Europe, and the imminent outbreak of World War II, were at the centre of attention.

Although I will refrain from an overall judgement of the historical importance of Bauer's economic theory, I have nonetheless identified far-reaching trains of thought that are reflected in today's global economic situation. Among them are the rise of global capital and the web of international money transfers; the subordination of political and social structures to the logic of circulation and accumulation of capital; the weakening of national economies, and the formation of decision-making centres. It is also worth citing the negative results of technologisation that Bauer warned of in RationalisierungFehlrationalisierung (Rationalisation and False Rationalisation, 1931), namely phenomena such as the rise of mass unemployment and the creation of a consumer society in which the media pushes uniform needs, values, and views. To use Marcuse's terminology: a one-dimensional society. 89 